\title{
YOUNG GENERATION'S PERCEPTION OF SMALL-TOWN DEVELOPMENT IN THE LAST TEN YEARS IN KALIANDA DISTRICT SOUTH LAMPUNG REGENCY
}

\author{
Ratu Nabillah ${ }^{1}$ \\ ${ }^{1}$ Geography-Regional Development, Universitas Gadjah Mada \\ Yogyakarta
}

Email corresponding: ratunabillah@mail.ugm.ac.id

\begin{tabular}{|c|c|c|}
\hline Submitted: & Accepted: & Published: \\
$01-08-2021$ & $02-08-2021$ & $30-09-2021$ \\
\hline
\end{tabular}

\begin{abstract}
The dichotomy of "village" and "city" that often occurs in development practice requires attention to the relationship between villages and cities. This linkage can be seen in the transitional area between rural and urban areas. The transition area is a small-town. A large number of small cities in Indonesia and the significant function of the existence of small towns make the development of small towns need attention. This study aims to analyze the perceptions of the younger generation on the development of small towns in Kalianda District, South Lampung Regency, and to analyze the relationship between the identity of the young generation against various indicators of small-town development. The variables in this study are divided into the economy, education, transportation, tourism, and other developments where there are various indicators of small-town development. Percentage Analysis and Chi-Square Analysis were used in the study. This study indicates that overall the younger generation has different views on the development of small towns, but 10 out of 16 indicators are considered to be in good development (stage 2). There are only three identities of respondents who have no relationship to small - town development: gender - tourism development, social media market development, social media - tertiary employment development.
\end{abstract}

Key words: perception, young generation, town development, small-town

\section{INTRODUCTION}

Much of the development theory and practice that occurs creates a dichotomy between "rural" and "city" (Tacoli, 1998). This is reflected in the division of policies based on spatial and sectoral lines when city planners often concentrate on urban nodes and pay less attention to rural development or agricultural development and village planners who also tend to ignore urban centers and define rural as only comprising areas, which contains agricultural land. In reality, the separation between rural and urban areas is not complete. One example of an activity that biases the separation of villages and cities is exemplified by Rijanta \& Suhardjo (2003) in DI Yogyakarta Province: the rural economy has been diversified, marked by a large amount of community income from the non-agricultural sector. Likewise, in cities, many urban households depend on rural economic activities for their survival. In line with this, Weeks (2010) explains that urban and rural areas are "continuum" ideas, which show that both influence each other, and it is difficult to represent each other's dichotomy. In fact, in a developed regional economy, rural-urban activities can be complementary and mutually beneficial for many regions.

There are transitional areas between villages and cities from rural to urban areas and vice versa, known as small towns. The categorization of small cities cannot be standardized across countries; many aspects can determine the size of a city both from physical, social, and economic aspects (Kasikoen, 2011). Owusu (2005) suggests that it would be better if city classification is closer to functional aspects than fundamental aspects (according to the context of the area and the problems to be studied). In seeing the rural-urban linkages, small towns are the right areas because these areas cannot be categorized explicitly into villages or cities. The transformation of urban to rural areas and vice versa is visible in small cities.

The existence of small towns is essential both for the surrounding rural areas and for 
larger cities. For example, Tacoli (2017) explains that small towns in regional development can act as 1) centers of demand or markets for agricultural products from rural areas, 2) centers of production and distribution of goods and services to rural areas, 3) centers of growth and consolidation of activities and rural non-farm employment, 4) attracting rural migrants from surrounding areas through the demand for nonagricultural labor, and 5) managing natural resources to respond to the needs of $a$ growing rural and urban population. Many other experts consider the urgency of small towns (see: Mainet \& Edouard, 2020, Senetra \& Szarek-Iwaniuk, 2020, and Sietchiping et al., 2014). In contrast to the interests played by small cities, Ramsey et al. (2016) argue that unfortunately, the focus of attention that has been given so far has always been on big cities or villages. In fact, the changes that occur in small cities are evident and very dynamic in various aspects. Wirth et al. (2016) analogized that small towns on the outskirts of rural areas are often seen as 'chronic patients' from regional policies who always need care but are never properly cared for so that they will never recover. A large number of small towns in Indonesia emphasizes that attention must be paid to these small towns.

Development is a dimension that involves many subjects and objects, including society. The community is an essential entity of an area and cannot be ignored or treated only as an object of development but is also involved as an implementer in the overall process. There will be community development through the transfer of knowledge from experts/policymakers to society (and vice versa) (Adhanani, 2013). The population growth of Kalianda District, which continues to increase every year, makes it essential for input from the community to ensure that Kalianda District becomes a city that is in line with the wishes of residents and other development actors, especially the South Lampung Regency Government.

This research is development research that refers to previous research conducted by Doug Ramsey, Alex Michalos, and Derrek Eberts with the title "Community Changes and Growth in Small Cities Resident Perceptions of Growth in Brandon City, Manitoba, Canada" in 2016. Research development is carried out on the selected sample, which is focused on the younger generation. In addition, data on the identity of the younger generation (respondents) and perceptions of small-town developments were also collected according to the context of the research area. The younger generation was chosen because data collection was carried out online, considering the research was carried out in the middle of the COVID-19 pandemic, which advocated limiting mobility. The younger generation is also considered to have an easier time filling out questionnaires online. The younger generation is also more active in seeing city developments directly or through social media (considering that recently social media is very active in spreading development news).

The objectives of this study are 1) to analyze the perceptions of the younger generation regarding changes in the development of small towns in Kalianda subdistrict, South Lampung regency, and 2) to analyze to analyze the relationship between the identity of respondents to perceptions of small town developments.

\section{METHODS}

This research is mixed-method research. A quantitative approach is used to make Percentage Analysis and Chi-Square Analysis. Meanwhile, a qualitative approach is used to analyze the results of quantitative findings in a descriptive manner interpreted from the results of a literature study.

The research location is located in Kalianda District, which is the capital of South Lampung Regency, Lampung Province, Indonesia. Kalianda sub-district consists of 3 wards/sub-districts and 26 villages. Of course, the most significant regional developments are in the sub-districts of Way Urang, Bumi Agung, and Kalianda, which have many economic centers and human settlements. Meanwhile, the surrounding villages are still dominated by agricultural land and also some residential areas. The map of the research location is shown in Figure 1.

Data was collected using an online questionnaire given the COVID-19 Pandemic, which requires us to prioritize safety by limiting mobility. 285 questionnaires were filled in correctly and adequately. In addition, researchers made direct observations to see the physical development of this small town.

Finally, the researchers conducted a documentation study on regional documents such as the South Lampung District Medium Term Development Plan/Rencana Pembangunan Jangka Menengah (RPJMD) in the last 10 years, the South Lampung Regency Spatial Plan/Rencana Tata Ruang Wilayah (RTRW) 2009-2029, and the Regional Apparatus Organization/Organisasi Perangkat 
Daerah (OPD) other documents that support research.

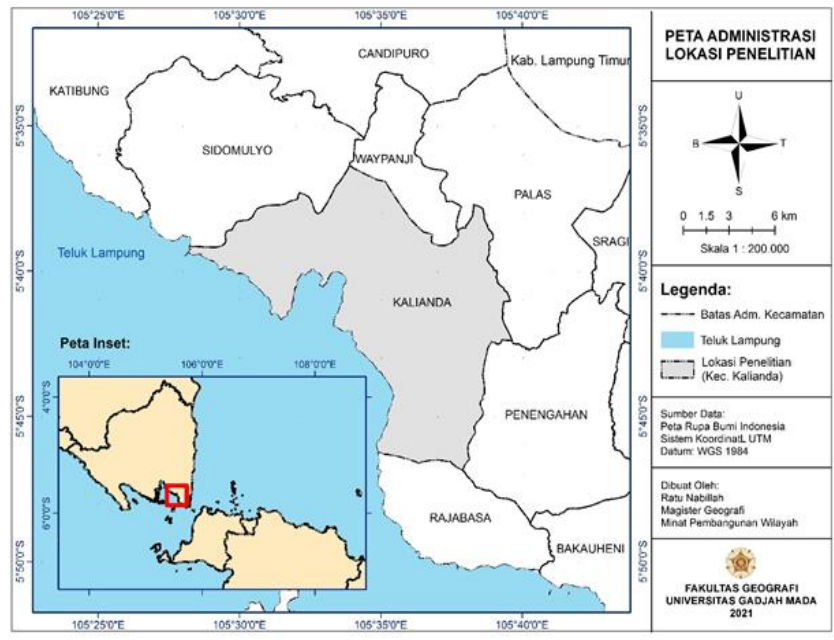

Figure 1. Research Location Map

The variables and indicators used in this study are listed in Table 1.

Data analysis using Percentage Analysis Technique and Chi-Square Analysis. Percentage analysis is used in making a percentage of people's perceptions of urban development based on their identity.

Table 1. Variables and Indicators

\begin{tabular}{cc}
\hline Variables & \multicolumn{1}{c}{ Indicators } \\
\hline Economy & $\begin{array}{c}\text { The crowd of Kalianda } \\
\text { Presidential Market Traders }\end{array}$ \\
& $\begin{array}{c}\text { Street vendors } \\
\text { Cafe, coffee shop, restaurant } \\
\text { Tertiary work field }\end{array}$ \\
\hline Education & $\begin{array}{c}\text { Quantity and quality of primary } \\
\text { education }\end{array}$ \\
\cline { 2 - 2 } & $\begin{array}{c}\text { Quantity and quality of secodary } \\
\text { education }\end{array}$ \\
\cline { 2 - 2 } & $\begin{array}{c}\text { Quantity and quality of higher } \\
\text { education }\end{array}$ \\
& $\begin{array}{c}\text { Quantitiy and quality of } \\
\text { additional education/courses }\end{array}$ \\
\hline Transportation & Public transportation \\
\hline Housing & The price of vacant land \\
& $\begin{array}{c}\text { The price of buying and selling } \\
\text { house }\end{array}$ \\
\cline { 2 - 2 } & The price of rented house \\
\hline Tourism & Tourist attraction \\
\cline { 2 - 2 } & $\begin{array}{c}\text { Number of hotels, resorts, and } \\
\text { etc. }\end{array}$ \\
\hline Others Development & Sport \\
& Electrical system \\
\hline Waste system \\
\hline Source:
\end{tabular}

The formula used is:

$$
P=f / n \times 100
$$

Explanation

$\mathrm{P}$ : Percentage

$f$ : Frequency of of each answer category $\mathrm{n}$ : Number of respondents

The index number used as the percentage criterion refers to Arikunto (1980) in Table 2.

Table 2. Percentage Criteria

\begin{tabular}{ccl}
\hline No & Percentage (\%) & \multicolumn{1}{c}{ Criteria } \\
\hline 1 & 100 & All of it \\
2 & $75-99$ & Most \\
3 & $51-74$ & More than half \\
4 & 50 & Half \\
5 & $25-49$ & Less than half \\
6 & $1-24$ & Fraction \\
7 & 0 & None \\
\hline
\end{tabular}

The number 5 (in Table 4) indicates "very well developed" development, 4 "well developing", 3 "moderately/stagnan developed, 2" less developing", and 1" very undeveloped".

Chi-Square analysis was used by using SPSS Version 24 software to analyze the relationship between respondent identity and perceptions of small-town developments. The hypothesis used is 1) Ho: There is no relationship between the identity of the respondent and the perception of the development of a small town. 2) H1: There is a relationship between the identity of the respondent and the perception of the development of a small town. The basis for decision making is used if the significance value of the Chi-Square test results $<0.05$, then $\mathrm{Ho}$ is rejected, and $\mathrm{H} 1$ is accepted. If the significance value of the Chi-Square test 
results $>0.05$, then $\mathrm{Ho}$ is accepted, and $\mathrm{H} 1$ is rejected.

Table 3. Identity of Respondents

\begin{tabular}{|c|c|c|}
\hline \multicolumn{2}{|c|}{ Identitiy of Respondents } & Summary $(n=285)$ \\
\hline \multirow[t]{2}{*}{ Gender } & Male & 120 \\
\hline & Female & 165 \\
\hline \multirow[t]{2}{*}{ Age } & $18-23$ & 50 \\
\hline & $24-28$ & 240 \\
\hline \multirow[t]{3}{*}{ Last Education } & SHS & 40 \\
\hline & Diploma's degree & 25 \\
\hline & At least Bachelor's degree & 220 \\
\hline \multirow[t]{7}{*}{ Job } & Student & 20 \\
\hline & College student & 90 \\
\hline & Civil servant/Police/Army & 5 \\
\hline & Freelancer & 5 \\
\hline & Enterpreneur/Traders & 40 \\
\hline & Honorary Employee & 20 \\
\hline & Etc. & 100 \\
\hline \multirow[t]{4}{*}{ Address } & Way Urang Sub-district & 130 \\
\hline & Bumi Agung Sub-district & 10 \\
\hline & Kalianda Sub-district & 60 \\
\hline & Apart from the three districts & 40 \\
\hline \multirow{2}{*}{$\begin{array}{l}\text { Following / Not Following Social Media about South } \\
\text { Lampung }\end{array}$} & Yes & 145 \\
\hline & No & 90 \\
\hline
\end{tabular}

Analysis of the perceptions of the younger

Table 4. Percentage of Perceptions of Small Town Development

\begin{tabular}{|c|c|c|c|c|c|}
\hline \multirow{2}{*}{ Variabel } & \multicolumn{5}{|c|}{ Perception about Development (\%) } \\
\hline & 5 & 4 & 3 & 2 & 1 \\
\hline \multicolumn{6}{|l|}{ Economy } \\
\hline The crowd of Kalianda Presidential Market Traders & 17.54 & 50.88 & 28.07 & 1.75 & 1.75 \\
\hline Street vendors & 22.81 & 36.84 & 28.07 & 5.26 & 7.02 \\
\hline Cafe, coffee shop, restaurant & 40.35 & 40.35 & 17.54 & 1.75 & 0 \\
\hline Tertiary work field & 3.51 & 26.32 & 64.91 & 3.51 & 1.75 \\
\hline \multicolumn{6}{|l|}{ Education } \\
\hline $\begin{array}{l}\text { Quantity and quality of primary education (elementary \& } \\
\text { kindergarten) }\end{array}$ & 8.42 & 49.12 & 38.6 & 3.51 & 1.75 \\
\hline Quantity and quality of secodary education (JHS \& SHS) & 8.77 & 42.11 & 45.61 & 3.51 & 0 \\
\hline Quantity and quality of higher education/University & 1.75 & 1.75 & 14.04 & 26.32 & 17.54 \\
\hline Quantitiy and quality of additional education/courses & 1.75 & 21.05 & 19.30 & 47.37 & 12.28 \\
\hline \multicolumn{6}{|l|}{ Transportation } \\
\hline Public transportation & 3.51 & 12.28 & 40.35 & 29.82 & 14.04 \\
\hline \multicolumn{6}{|l|}{ Housing } \\
\hline The price of vacant land & 10.53 & 49.12 & 49.12 & 3.51 & 0 \\
\hline The price of buying and selling house & 14.04 & 42.11 & 42.11 & 7.02 & 0 \\
\hline The price of rented house & 7.02 & 43.86 & 40.35 & 8.77 & 0 \\
\hline \multicolumn{6}{|l|}{ Tourism } \\
\hline Tourist attraction & 28.07 & 54.39 & 17.54 & 0 & 0 \\
\hline Number of hotels, resorts, and etc. & 0 & 33.33 & 42.11 & 22.81 & 1.75 \\
\hline \multicolumn{6}{|l|}{ Others Development } \\
\hline Sport & 7.02 & 43.86 & 29.82 & 10.53 & 8.77 \\
\hline Electrical system & 14.04 & 50.88 & 24.56 & 10.53 & 0 \\
\hline Waste system & 3.51 & 26.32 & 45.61 & 19.30 & 5.26 \\
\hline
\end{tabular}

\section{RESULT AND DISCUSSION}

The recapitulation of the respondent's identity is shown in Table 3. generation on the development of small cities was carried out by using the Percentage 
Analysis, the results of which are shown in Table 4.

\section{Young Generation's Perception of Small Town Development in The Last Ten Years Economy}

In terms of the economic sector, In terms of the economic sector, respondents think that the development of Kalianda District as a whole is in a developing stage. Kiik (2006) suggests that the activities in a trading center, such as a traditional market, as one of the sub-systems of a trading center in a region, are parameters that can be used to determine the growth and economic dynamics of a region. The higher the activity in the market is an indicator of a region's more dynamic economic wheels. More than half of the respondents $(50.88 \%)$ considered the development of Kalianda Market to be in the developing stage. This is natural because even though there is only one market in terms of numbers, namely Kalianda Market, this market is the center of economic activity that serves Kalianda District and serves other subdistricts around Kalianda District. Its location is in the heart of the sub-district and is evidenced by the market operating hours open every day from 04.00 West Indonesian Time (WIB) until late at night, unlike the markets in the surrounding sub-districts, which have special market days. Kalianda Market undoubtedly hopes for smaller areas (surrounding villages) and larger areas (big cities). Based on the results of a pre-survey conducted on April 5-10, 2021, Kalianda Market for several commodities has succeeded in becoming a meeting place for rural and urban commodities. For example, in Kalianda Market, there is 1 prominent coffee collector and 3 sellers also coffee grinders. The coffee is taken from various coffee farmers who come from surrounding villages. After experiencing the processing of coffee beans into ground coffee, the coffee is sent to major cities in Indonesia to become Lampung Coffee, which is recognized for its excellence by the world. This means that Kalianda Market has succeeded in connecting village products to reach the city for the coffee commodity.

On the other hand, Kalianda Market is also a transit point for imported goods (domestic and foreign) purchased by the villagers. The most obvious example is the emergence of shops for agricultural inputs (such as fertilizers, agricultural tools, etc.) in the Kalianda Market. These two examples are following those stated by Tacoli (2017) \& Karg et al. (2019), where small cities have a role as outlets for rural products, intermediary market centers in larger markets, import goods distribution centers, processing centers agriculture and resources in the surrounding rural areas, and rural community service centers. With the infrastructure and noninfrastructure development that continues to be carried out in South Lampung Regency and Lampung Province, Kalianda Market in the future is very likely to continue to develop.

$36.84 \%$ of respondents considered street vendors (PKL) in small cities to be in the developing stage. This is reasonable considering a large-scale construction and arrangement in four places, namely the Bomb Pier, the Way Handak Sports Building (GOR) equipped with WiFi Park, Kalianda Square (Pemda Field), and Kalianda Educational Garden. The arrangement of these four places has a significant impact on the development of street vendors because providing proper places for street vendors is included in the arrangement of these four places so that there is no image of a slum little town. For example, at the beginning of the Jermaga Bom, no more than 10 street vendors lived in old non-permanent buildings. After the expansion and arrangement were carried out, non-permanent street vendors and street vendors who occupied permanent buildings also grew and became tidier. If arranged neatly, street vendors provide the advantages of a city. Widyaningrum (2009) argues that street vendors can be seen as part of economic activities that provide livelihoods for city residents and can even become part of the city's attractiveness. Of course, on the contrary, when the arrangement is not carried out, it will worsen the city's image. The Special Region of Yogyakarta (DIY), for example, has an area that collects street vendors so that it becomes one of the DIY tourism icons: Malioboro Road. The results of research by Nirathron \& Yasmeen (2019) reveal that street vendors in 4 districts in Bangkok (Bangrak, Pathumwan, Phranakorn, and Sampthanthawong) absorb employment opportunities for people of productive age who have not yet got a job so that they get a steady income every month which can reach 15,000 baht or around Rp.6,800,000.00, and increase the chances of the emergence of restaurant accommodation or lodging. Big cities with various PKL problems, if appropriately managed, will bring benefits to 
their area, which means that small cities with street vendor problems that are not as complicated as big cities will undoubtedly find it easier to manage street vendors to be a source of profit both for the community and for their citizens.

The public perception of the development of cafes, coffee shops, and restaurants in total $(80.70 \%)$ is at a very advanced and developing stage. Cafes, coffee shops, and restaurants in the past three years have experienced an increase in numbers. However, if we look at it more carefully, not all of these cafes, coffee shops, and restaurants in Kalianda District can last long. In simple terms, it can be said: "appears one, close one." In Central Place Theory, Christaller argues that if there is not enough demand or at least it reaches a certain point, business people will not offer/open their business in that place. This means that goods and services have a range, and producers have a minimum market area to produce (threshold) (King, 2020). From this viewpoint, goods and services can be grouped based on their Order: where Order I are high-level goods that are rarely purchased, such as cars, Order II are goods that are rarely purchased such as beds, Order III are goods that are not bought every day such as clothes, and Order IV is goods that are purchased every day such as sugar and salt (Nainggolan, 2013). Based on this theory, food and drinks are indeed loworder items that must be purchased every day, but eating and drinking in cafes, coffee shops, and restaurants is not an activity carried out by the community every day. The number of cafes or coffee shops that are too large is not covered by the small number of people in small cities, especially young people who visit. It makes so many experiences of bankruptcy.

More than half of respondents (64.91\%) assessed that tertiary employment is in the intermediate development stage, not too fast but also not slow. The development that does not slow down occurs because the town's development creates many job opportunities in the tertiary sector; one example, as mentioned earlier, is that cafes, coffee shops, and restaurants create additional employment opportunities. The study of tertiary employment opportunities in small towns needs to be a particular topic because discussing job opportunities in small cities is a complex discussion that needs to be viewed from various sides.

\section{Education}

In terms of education, the responses obtained for each variable are pretty diverse. The development of the quality and quantity of primary education is considered to be well developed (49.12\%), secondary education with sufficient development (45.61\%), higher education/university, and tutoring with less development (respectively 26.32\% and $47.37 \%$ ). The development of primary education and secondary education has developed quite well, which is considered normal. This is because education development starting from primary education (elementary school or kindergarten) is a layered policy from the central, regional, and regional levels. For example, the Lampung Provincial Education Office consistently carries out educational quality development programs such as Lampung Teaching, which began in 2014 and details the current era of governor leadership (2020-2024) (http://www.lampungprov.go.id). It is different from higher education which requires much consideration in its development, so that the scale of a small town is not appropriate if it is focused on developing higher education. Moreover, Lampung Province has set a focus area for higher education development, Jati Agung Subdistrict, South Lampung Regency, which is also a peri-urban area of Bandar Lampung City, marked by the presence of the Sumatra Institute of Technology (ITERA). Tutoring (Bimbel) is a matter of great concern for its existence. Moreover, in the past 5 years, the existence of Information and Communication Technology (ICT) has increased the existence of Bimbel Online, so that learning is not fixed by location. As stated by Suryani, (2010), ICT also can provide a way for dynamic and collaborative learning. By using internet our learning is not limited to the school hours, demographically where we are, and who our teachers are. We can access internet anytime and anywhere. Automatically students in small cities will try to study with preeminent tutoring institutions nationally and even internationally, even though this is not the case as a whole.

\section{Transportation}

$40.35 \%$ of respondents have a moderate development perception of the development of public transportation. A unique phenomenon in the past few years in this small city is online motorcycle taxis but not under the auspices of national scale companies such as Gojek, Grab, or Maxim, but independent ojek that can be ordered through the WhatsApp application. For other 
public transportation such as angkot and travel cars, the development tends to stagnate in terms of fleets and comfort. There is indeed no inter-urban transportation in small cities (other than ojek). This is because almost every family has private transportation and a small area, so that public transportation is difficult to develop properly. Existing public transportation only serves between sub-districts or between regencies/cities such as the Trans Lampung Bus to and from Bandar Lampung City, travel cars and public buses to and from Bandar Lampung and Bakauheni Port, and angkot that serve between sub-districts in a very limited number. It is still suitable to be developed, like the inter-district and inter-regency/city transportation system. The transportation system in a small town is the most convenient to use ojek or private vehicles such as a bicycle, motorbike or car. So far, the government (village, sub-district, or regency) is still focused on fulfilling proper road infrastructure to remote villages. After that, the inter-sub-district transportation system, especially those connecting small cities to rural areas around it, really needs to be improved considering the significant benefits obtained from an excellent rural-urban transportation system. Evidenced by Litman (2017) in his research which reveals

... the importance of a sound transportation system between villages and cities, including 1) Rural public transport can be an essential force in supporting local economies by connecting residents (especially non-drivers) with local business and employment opportunities 2) The number of villagers traveling both within the village and outside the village is $33 \%$ more than the urban population. Good rural-urban transport links will help their journey. 3) The proportion of the population living in the village is dominated by the elderly. So, a sound transportation system will help the elderly in accessing elderly's health needs.

One other transportation system that is being planned to be developed in South Lampung Regency is the train. This is considered very appropriate if it is realized. For example, South Lampung Regency, which is the gateway to the island of Sumatra, will be perfect if there are many transportation modes after the descent of commuters from Bakauheni Crossing Port to other cities in Lampung Province.

Housing

Overall, the respondents assessed that the development of buildings in this small town is developing well. In terms of quantity, it is clear that the number of boarding houses or rented houses in this small town has increased in the last 10 years. This is inseparable from the infrastructure development carried out in Kalianda District, South Lampung Regency, and Lampung Province. The infrastructure development that has attracted the most national and even international attention in South Lampung Regency is constructing the Trans Sumatera Toll Road (JTTS) for the Bakauheni-Terbanggi Besar Section, the Executive Pier at the Bakauheni Crossing Port, and the revitalization of Radin Inten II Airport. Much literature explores the relationship of infrastructure development to economic growth (Datta, 2012; Ahlfeldt, 2011; Faber, 2014; Deng, et al. 2019), where economic growth can be broadly defined as a new social agglomeration that occurs because infrastructure development then affects multipliers such as the emergence of industry or other small-scale economies. In line with what Ball \& Nanda (2014) stated in Deng et al. (2019) where infrastructure investment can increase local business activities where this activity will generate many commercial buildings to support the process, such as the appearance of rooms or rental houses for employees.

\section{Tourism}

Tourism is one of the mainstay sectors for the economy of the South Lampung Regency. Endowed with the physical condition of the area, which is dominated by the coast and two mountains, tourism is proliferating in this regency, including in the Kalianda District. More than half of the respondents (54.39\%) considered developing the quality and quantity of well-developed tourism objects. However, unfortunately, hotels and resorts are considered to be experiencing stagnant development. This is because tourists visiting the beaches in Kalianda sub-district or its surroundings are dominated by circular tourists, coming during the day and returning at night. After all, the reach of tourist visitors is predominantly from districts/cities around South Lampung and local tourists from South Lampung Regency. Tourism development must be seen from different sides comprehensively and pay attention to regional aspects: physical and social culture. The positive impact of tourism has been proven by various studies, including the economic impact in the form of increased employment opportunities, increased income, 
and increased living standards. Social impacts include recognizing local culture, increased social welfare, and increased recreation (Tsundoda \& Mendlinger, 2009).

On the other hand, a dilemma occurs with tourism development due to negative impacts such as the clearer social strata (the rich more affluent, and vice versa) even in some areas (for example, in New Hampshire, the results of research by Tsundoda \& Mendlinger, 2009) where tourism does not have any effect for regional development. There is no general conclusion that tourism has a positive or negative impact on regional development. The territorial context from various points of view must be considered in planning tourism development. One of the most important things that must be underlined in tourism development is to adhere to the concept of Sustainable Tourism, in which tourism must fully take into account the current and future economic, social and environmental impacts, meeting the needs of visitors, industry, the environment and the host community (UNWTO, 2013) which in short terms tourism should provide benefits for all aspects: Leave No One Behind.

\section{Others Development}

The development of sports infrastructure is considered to be well developed (43.86\%). As previously canceled, South Lampung Regency, which is part of the coast, provides opportunities for the development of the sports sector. Kalianda Subdistrict, which is dominated by the plains, is suitable for cycling, accompanied by sea views. Water sports that can also be done in Kalianda District are kayaking and canoeing. The most significant progress of sports infrastructure is when Kab. South Lampung, especially Kalianda District as the capital, hosted the 2014 Lampung Provincial Sports Week (Porprov). The Regency Government, assisted by the Provincial Government, built 1 sports stadium (for football and athletics), 1 sports stadium (for basketball), and various revitalizations of many infrastructures. Other sports include collaborating with private managers. Unfortunately, almost 10 years of Porprov have passed, the quality of these buildings is not all well preserved. Some buildings have been converted into non-sports activities.

Electrical energy is considered to have developed well (50.88\%). The most obvious thing is the frequency of power outages that have become less frequent in recent years than the past 10 years, wherein one week, this small town could experience power outages 2 to 3 times a week. Now, the frequency of blackouts is sporadic, only about 1 to 2 times in two months. As for the solid waste system development, $40.35 \%$ of respondents considered that the development was stagnant. For the waste transportation system managed by the Settlement and Landscaping Office, South Lampung Regency Government, has its own scheduled trash day. Many other developments can still be done, such as increasing the number of bins in public places, which is still lacking. I It is necessary to remind that as the world becomes more urbanized and developed, consumption rates rise. An inevitable consequence of more consumption is the rapid increase in the amount of solid waste produced (McAllister, 2015). The waste bank system also does not exist in this small city; there have been many studies exploring the magnitude of the benefits of having a waste bank (Safiah \& Julipriyanto, 2017; Syafrudin et al. 2019; Selomo et al. 2016; Suryani, 2014). Lessons from the small towns of Karjat and Suryapet in India reveal the success of waste banks in supporting sustainable waste management, starting with leaders who dare to create innovations (Ahluwalia \& Patel, 2018).

The Relationship Between The Identity of Respondents To Perceptions of Small Town Developments

The following section describes the perception of changes in Kalianda District in the last 10 years seen through the Chi-Square Test: there are any significant differences based on six demographic characteristics, namely gender, age, latest education, job, address, and social media. The tabulated results of the Chi-Square Analysis are shown in Table 5.

The results of Table 5 show that there are 3 categories of couples where there are no significant differences, namely 1 ) gender on perceptions of the development of tourist objects, 3) social media on perceptions of market development, and 3) social media on perceptions of tertiary employment development. This means that there is no relationship between the gender of the respondent on the perception of the development of a tourist attraction, and there is also no relationship between respondents who follow or do not follow social media regarding Kab. South Lampung on perceptions of tertiary market development and employment.

Social Media - Perceptions of Tertiary Employment and Market Development 
The absence of a relationship between respondents who follow and do not follow social media regarding South Lampung Regency on perceptions of market development and tertiary employment is natural because information about market developments on social media regarding Kalianda District or South Lampung Regency is scarce. The content of social media with many followers is dominated by information about tourism and culinary. Meanwhile, lesson that South Lampung Regency can learn is by proving the prowess of Information and Communication Technology, one of which is by activating the social media of each Regional Apparatus Organization (OPD), which can later develop by establishing various collaborations with the private sector.

\section{Gender - Perceptions of Tourism Object Development}

The Chi-Square test results show that

Table 5. Chi-Square Analysis about The Relationship Between The Identity of Respondents To Perceptions of Small Town Developments

\begin{tabular}{|c|c|c|c|c|c|c|c|c|c|c|c|c|c|c|c|c|}
\hline & 1 & 2 & 3 & 4 & 5 & 6 & 7 & 8 & 9 & 10 & 11 & 12 & 13 & 14 & 15 & 16 \\
\hline$G$ & $*$ & $*$ & $*$ & $*$ & $*$ & $*$ & $*$ & $*$ & $*$ & $*$ & $*$ & $*$ & $*$ & $*$ & $*$ & 0.158 \\
\hline$A$ & $*$ & $*$ & $*$ & $*$ & $*$ & $*$ & $*$ & $*$ & $*$ & $*$ & $*$ & $*$ & $*$ & $*$ & $*$ & $*$ \\
\hline$E$ & $*$ & $*$ & $*$ & $*$ & $*$ & $*$ & $*$ & $*$ & $*$ & $*$ & $*$ & $*$ & $*$ & $*$ & $*$ & $*$ \\
\hline J & $*$ & $*$ & $*$ & $*$ & $*$ & $*$ & $*$ & $*$ & $*$ & $*$ & $*$ & $*$ & $*$ & $*$ & $*$ & $*$ \\
\hline Ad & $*$ & $*$ & $*$ & $*$ & $*$ & $*$ & $*$ & $*$ & $*$ & $*$ & $*$ & $*$ & $*$ & $*$ & $*$ & $*$ \\
\hline$S$ & 0.185 & $*$ & $*$ & 0.172 & $*$ & $*$ & $*$ & $*$ & $*$ & $*$ & $*$ & $*$ & $*$ & $*$ & $*$ & $*$ \\
\hline
\end{tabular}

Source: Reasearch Result, 2021

Explanation:

$\begin{array}{llll}\text { G } & \text { : Gender } & 1 & \text { : Market } \\ \text { house } & & & \\ \mathrm{A} & \text { : Age } & 2 & \text { : Street vendors } \\ \mathrm{E} & \text { : Education } & 3 & \text { : Cafe } \\ \mathrm{J} & \text { : Job } & 4 & \text { : Tertiary work field } \\ \mathrm{Ad} & \text { : Address } & 5 & \text { : Primary edu. } \\ \mathrm{S} & \text { : Social media } & 6 & \text { : Secondary edu. }\end{array}$

information about development in Kab. South Lampung is mainly shared by official accounts managed by the Regency Governments (Pemkab) of South Lampung, with fewer followers than other unofficial accounts. The development of Kalianda Market will undoubtedly be more accurate if seen directly or through documentation owned by the South Lampung Regency Government. The same is the case with information about tertiary employment, which is still very dear to him because of limited information. Not many connections or cooperation between the district government and private parties that provide jobs should still be developed. As is done by the Sleman Regency Government in Yogyakarta Province, one of which is under the auspices of the District Manpower Office which often holds job fairs (can be seen on Instagram @disnakersleman). A valuable

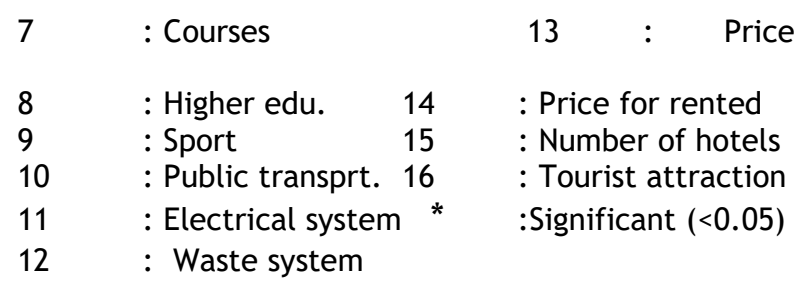

there is no relationship between gender and perceptions of the development of a tourist attraction. This means that both men and women have the same perception of the development of tourist objects.

\section{CONCLUSION}

The younger generation's perception towards the development of small cities based on percentage analysis resulted in mixed opinions. In the last 10 years from an economic perspective, four indicators are considered to be in a good development stage (stage 4: the crowd of Kalianda presidential market traders, street vendors, cafe/coffee shop/restaurant), and one indicator is in a stagnant stage of development (stage 3: tertiary work field). In terms of education, one indicator is considered to be in a good development stage (stage 4: quantity and 
quality of primary education), one indicator is assessed at a stagnant stage of development (stage 2: quantity and quality of secondary education), and two indicators are assessed at a developmental stage less developed (stage 2: quantity and quality of higher education and courses). In terms of transportation, public transportation is considered to be in a stagnant development stage (stage 3). Meanwhile, in terms of housing, the younger generation assessed the uniform development of the three indicators in a stagnant stage (stage 3: the price of vacant land, buying / selling houses, and rented houses). Regarding tourism, the development of the number of tourist objects is considered to be in a well-developed stage (stage 2). Still, the number of accommodation accommodations is considered to be in a stagnant development stage (stage 3). Finally, from another development point of view, the development of sports infrastructure and electrical systems is considered a good development stage (stage 2 ). In contrast, the solid waste system is considered stagnant (stage 3 ).

The results of the Chi-Square Analysis show that there is only a pair between the respondent's identity on the perception of small-town development that is not related, namely social media with market developments and tertiary employment, and gender with the development of tourist objects.

\section{ACKNOWLEDGEMENT}

The author would like to express his deepest gratitude to the people of the South Lampung Regency, especially the younger generation who are willing to become respondents.

\section{REFERENCES}

Adhanani, R. A. N. (2013). Partisipasi Masyarakat dalam Perencanaan Teritorial (Studi Komparasi: Borobudur dan Nantes). Jurnal Pembangunan Wilayah \& Kota, 9(4), 355. https: / / doi.org/10.14710/pwk.v9i4.6674

Ahlfeldt, G. M. (2011). The Train has Left the Station: Do Markets Value Intracity Access to Intercity Rail Connections? German Economic Review, 12(3), 312335. https://doi.org/10.1111/j.14680475.2010.00521.x

Datta, S. (2012). The Impact of Improved Highways On Indian Firms. Journal of Development Economics, 99(1), 46-57. https://doi.org/10.1016/j.jdeveco.2011
.08 .005

Deng, X., Nanda, A., \& Ong, S. E. (2019). Does Infrastructure Spending Lead To Price Effects In The Property Market? Evidence From Major Cities Across India. Regional Studies, 53(12), 1747-1760. https: / / doi.org/10.1080/00343404.2019 .1619925

Faber, B. (2014). Trade Integration, Market Size, And Industrialization: Evidence From China's National Trunk Highway System. Review of Economic Studies, 81(3), 1046-1070. https: / /doi.org/10.1093/restud/rdu010

Karg, H., Bellwood-Howard, I., Akoto-Danso, E. K., Schlesinger, J., Chagomoka, T., \& Drescher, A. (2019). Small-Town Agricultural Markets in Northern Ghana and Their Connection to Rural and Urban Transformation. European Journal of Development Research, 31(1), 95-117. https: //doi.org/10.1057/s41287-0180171-2

Kasikoen, K. M. (2011). Tipologi Perkotaan di Kabupaten Cilacap. Planesa, 2(1), 65-72.

King, L. J. (2020). The Web Book of Regional Science. Sponsored by Regional InputOutput Analysis By Series Editor: In The Web Book of regional Science.

Mainet, H., \& Edouard, J.-C. (2020). The Role of Small And Medium Sized Towns In Eastern Africa Mountains: New Opportunities Or Challenged Position? Rural-Urban Dynamics in the East African Mountains, 27-45. https: / /doi.org/10.4000/books.africae. 1 198

Nainggolan, P. (2013). Analisis Penentuan Pusat-Pusat Pertumbuhan Ekonomi Di Kabupaten Simalungun. Jurnal Ekonomi Dan Keuangan, 1(12), 14770. https://doi.org/10.31227/osf.io/gq235

Nirathron, N., \& Yasmeen, G. (2019). Street Vending Management In Bangkok: The Need To Adapt To A Changing Environment. The Journal of Public Space, 4(Vol. 4 N. 1 | 2019 | FULL ISSUE), 15-32. https://doi.org/10.32891/jps.v4i1.562

Ramsey, D., Michalos, A., \& Eberts, D. (2016). Community Changes And Growth In Small Cities: Resident Perceptions of Growth In Brandon, Manitoba, Canada. Growth and Change, 47(4), 682-699. https: / / doi.org/10.1111/grow.12150

Rijanta, R., \& Suhardjo. (2003). Defining Rural Diversification in A Small-Farming Region: The Case of Yogyakarta Special Province, Indonesia (pp. 107-124). 
Indonesian Journal of Geogrphy, Vol. 35 No. 2.

Safiah, S. N., \& Julipriyanto, W. (2017). Manfaat Bank Sampah Bagi Masyarakat Di Dusun Semali Desa Salamkanci Kecamatan Bandongan Kabupaten Magelang. (Study Bank Sampah Semali Berseri). Jurnal REP (Riset Ekonomi Pembangunan), 2(2), 165-184. https://doi.org/10.31002/rep.v2i3.528

Selomo, M., Birawida, A. B., \& Mallongi, A. (2016). The Waste Bank is One of Good Solusion for Handling Waste in Makassar City. Jurnal MKMI, 12 no 4(Desember), 232-240.

Senetra, A., \& Szarek-Iwaniuk, P. (2020). Socio-Economic Development of Small Towns In The Polish Cittaslow Network - A Case Study. Cities, 103(April). https://doi.org/10.1016/j.cities.2020.1 02758

Sietchiping, R., Kago, J., Zhang, X. Q., Tuts, R., \& Reid, J. (2014). The Role Of Small And Intermediate Towns In Enhancing Urban-Rural Linkages For Sustainable Urbanization. Regional Development Dialogue, 35(March 2019), 48-62.

Suryani, A. (2010). ICT in Education: Its Benefits, Difficulties, and Organizational Development Issues. Jurnal Sosial Humaniora, 3(1), 106-123. https://doi.org/10.12962/j24433527.v3i 1.651

Suryani, A. S. (2014). Peran Bank Sampah Dalam Efektivitas Pengelolaan Sampah (Studi Kasus Bank Sampah Malang). Jurnal Aspirasi, 5(1), 71-84.

Syafrudin, Junaidi, \& Ramadha, B. S. (2019). Inisiasi Pembentukan Bank Sampah di RT 03 RW 05 Kelurahan Gedawang Kota Semarang. Jurnal Pasopati, 1(2), 28-33.

Tacoli, C. (1998). Rural-Urban Interactions: A Guide to The Literature. 10(1), 147-166.

Tsundoda, T., \& Mendlinger, S. (2009). Economic and Social Impact of Tourism on a Small Town: Peterborough New Hampshire. Journal of Service Science and Management, 02(02), 61-70. https://doi.org/10.4236/jssm.2009.2200 9

Weeks, J. R. (2010). Defining Urban Areas. Remote Sensing and Digital Image Processing, 10(May 2010), 33-45. https: / /doi.org/10.1007/978-1-40204385-7_3

Widyaningrum, N. (2015). Kota Dan Pedagang Kaki Lima. Jurnal Analisis Sosial, 14(1), 1-18.

Wirth, P., Elis, V., Müller, B., \& Yamamoto,
K. (2016). Peripheralisation of Small Towns In Germany And Japan - Dealing With Economic Decline And Population Loss. Journal of Rural Studies. https://doi.org/10.1016/j.jrurstud.2016 .07 .021

Master and PhD Thesis

McAllister, J. (2015). Factors Influencing Solid-Waste Management in the Developing World. Master Thesis on Geography Utah State University, in https://digitalcommons.usu.edu/cgi/vie wcontent.cgi?article $=1537 \&$ context=grad reports

Kiik, V. M. (2006) Kajian Faktor-Faktor yang Mempengaruhi Tidak Optimalnya Fungsi Pasar Tradisional Lolowa dan Pasar Tradisional Fatubenao Kecamatan Kota Atambua Kabupaten Belu. Tesis pada Magister Pembangunan Wilayah dan Kota Universitas Diponegoro dalam: https: //core.ac.uk/reader/11717300

Owusu, G. (2005). The Role Of District Capitals In Regional Development: Linking Small Towns, Rural-Urban Linkages And Decentralization In Ghana. PhD Thesis on Department of Geography Faculty of Social Sciences and Technology Management Norwegian University of Science and Technology, NTNU Trondheim, INhttps: / / www.researchgate.net/publica tion/250276580_The_Role_of_District_Ca pitals_in_Regional_Development_Linking Small_Towns_RuralUrban_Linkages_and_Decentralisation_in_ Ghana

Book

Arikunto, S. (1998). Prosedur Penelitian Suatu Pendekatan Praktek. Jakarta: PT. Rineka Cipta

Regional Documents

Peraturan Daerah (PERDA) No 15 Tahun 2012 Tentang Rencana Tata Ruang Wllayah Kabupaten Lampung Selatan 2011 - 2031 in:

https://peraturan.bpk.go.id/Home/Detai ls/99997/perda-kab-lampung-selatan-no15-tahun-2012

Rencana Pembangunan Jangka Menengah (RPJMD) Kabupaten Lampung Selatan (2015-2019)

Rencana Pembangunan Jangka Menengah (RPJMD) Kabupaten Lampung Selatan. (2020-2024).

Online Manuscripts

Ahluwalia, I. J. \& Patel, U. (2018). Solid Waste Management in India an Assessment of Ressource Recovery and 
Environmental Impact. Working Paper No. 356. Indian Council fof Research on International Economic Relation in: https://www.researchgate.net/publicati on/340132854_Solid_Waste_Management in_India_An_Assessment_of_Resource_R ecovery_and_Environmental_Impact

Lampung Provincial Government Official Website. (2014). In:

https://lampungprov.go.id/detailpost/program-lampung-mengajar

Litman, T. (2017). Public Transportation's Impact on Rural and Small Towns. United States of America: Avital Mobility Link from The American Public Transportation Association (APTA). In: https: / /www.apta.com/wpcontent/uploads/Resources/resources/re portsandpublications/Documents/APTARural-Transit-2017.pdf

Tacoli, C. (2017). Small Towns, Rural-Urban Linkages, and Regional Development in: https://www.urbanet.info/rural-urbanlinkages/

United Nation World Tourism Organization. (2013). Sustainable Development. In: https: / / www. unwto.org/sustainabledevelopment) 